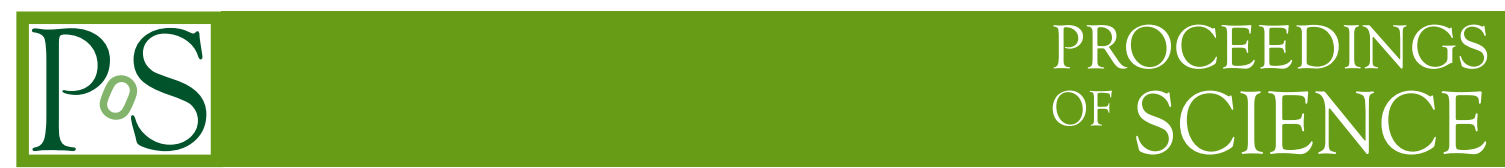

\title{
ILIAS and the World's Underground Laboratories
}

\section{N.J.C. Spooner (on behalf of the ILIAS collaboration)*}

Department of Physics and Astronomy, University of Sheffield, Sheffield, S3 7RH, UK.

E-mail: n.spooneresheffield.ac.uk

This is a brief review and comparison of the status of the underground laboratories in Europe and the world, covering in generic fashion the key important comparison issues and motivations for the infrastructures now and in the future.

Identification of dark matter 2008

August 18-22, 2008

Stockholm, Sweden

${ }^{*}$ Speaker. 


\section{Introduction}

The very deep underground laboratories of the world offer access to the best in quiet environments. Quiet from cosmic-ray muon flux but also, for increasing numbers of experiments, from vibration noise, electrical noise, natural radiation, radon gas and even biological contamination. Realisation of this diversity of use and benefit is starting to generate a revolution of development. Large new experiments are planned for particle astrophysics with many laboratories pushing expansion schemes and new deep laboratories being built. However, there is also a new generation of experiments outside the field of physics starting up. The discipline of Underground Particle Astrophysics is transforming into a divers field, becoming a sub-topic of a field called Underground Science.

\section{The World's Deep Laboratories}

As an illustration of the situation shown in Figure 1 is a table comparing characteristics of the world's current and up-coming most well known deep underground sites and in Figure 2 an overview table of the experimental activity and status of expansion plans where known (see also [1] and [2] and related sources). Of most interest to users is often the depth as this is related to the level of cosmic ray shielding provided by the rock. Traditionally this is given in m.w.e. (meters water equivalent), the depth normalised to the density of water. However, a better comparison, which naturally accounts for the averaging of the rock cover, is to use the muon flux. It should be noted here that there are a much larger number of underground laboratories at shallower depth not shown here, for instance as covered in Europe by the organisation CELLAR [3] and [4]. In general these are less than $200 \mathrm{~m}$ deep and are used for low background measurements of materials.

There is a significant range of characteristics observed here that reflect not just the needs of the science but also constraints due to geographic and local economic factors and the need usually to piggyback off an existing underground infrastructure, such as road tunnel or deep mine. This situation introduces challenges for the laboratories such as the need to cooperate closely with the host owners. These factors have partly limited the number of sites and the scope sites have for expansion. Recognising this there has been a trend in recent years toward better coordination between laboratories to improve efficiency, including moves toward better coordination in allocation of space. An example of the need for this is with dark matter experiments. Efforts will be needed to move next generation dark matter experiments to sites with the necessary depth, while other classes of experiment, such as liquid argon for use in proton decay, may be able to function at shallower depths [5]. It will be important to allocate such experiments space at the appropriate depth in order to use available space most efficiently.

In Europe the laboratory coordination is run first by the highly successful organisation ILIAS (Integrated Large Infrastructures for Astroparticle Science) [6], funded by the European Union. ILIAS involves over 20 institutes representing around 1500 scientists with interest in underground physics and gravitational waves. ILIAS comprises six networks, three joint research projects and a trans-national access programme (TA). A specific laboratory network has produced joint safety training and policy activity and, through regular meetings between senior representatives, progress toward coordinating science policy. 


\begin{tabular}{|c|c|c|c|c|c|}
\hline Site & $\begin{array}{l}\text { Location and } \\
\text { access }\end{array}$ & Current space & $\begin{array}{l}\text { Depth and } \\
\text { muon flux }\left(\mu \mathrm{m}^{-2} \mathrm{~s}^{-1}\right)\end{array}$ & $\begin{array}{l}\text { Rock and radon } \\
\left(\mathrm{Bq} \mathrm{\textrm {m } ^ { 3 } )}\right.\end{array}$ & Neutrons $\left(\mathrm{m}^{-2} \mathrm{~s}^{-1}\right)$ \\
\hline \multicolumn{6}{|c|}{ Europe } \\
\hline BNO & $\begin{array}{l}\text { Andyrchi, Russia; } \\
\text { independent tunnel }\end{array}$ & $\begin{array}{l}3 \text { halls: } 24 \times 24 \times 16 \mathrm{~m}^{3} \\
60 \times 10 \times 12 \mathrm{~m}^{3} ; 40,000 \mathrm{~m}^{3}\end{array}$ & $\begin{array}{l}850 \text { m.w.e. and } 4700 \text { m.w.e. } \\
\text { (SAGE area); } 3.03 \pm 0.19 \times 10^{-5}\end{array}$ & $\begin{array}{l}40 \\
\text { norite rock }\end{array}$ & $\begin{array}{l}1.4 \times 10^{-3}(>1 \mathrm{MeV}) \\
6.28 \times 10^{-4}(>3 \mathrm{MeV})\end{array}$ \\
\hline BUL & $\begin{array}{l}\text { Boulby mine, UK; } \\
\text { vertical }\end{array}$ & $1,500 \mathrm{~m}^{2}$ & $\begin{array}{l}2800 \text { m.w.e. under flat surface; } \\
4.5 \pm 0.1 \times 10^{-4}\end{array}$ & $\begin{array}{l}1-5 \\
\text { salt }\end{array}$ & $1.7 \times 10^{-2}(>0.5 \mathrm{MeV})$ \\
\hline CUPP & $\begin{array}{l}\text { Pyhasalmi mine, } \\
\text { Finland; vertical }\end{array}$ & $\begin{array}{l}>1000 \mathrm{~m}^{2} \text { spaces no } \\
\text { longer used by the mine }\end{array}$ & down to $1400 \mathrm{~m}$ & pyrite ore, zinc ore & - \\
\hline LNGS & $\begin{array}{l}\text { Gran Sasso, Italy; } \\
\text { road tunnel }\end{array}$ & $\begin{array}{l}3 \text { halls plus tunnels total } \\
17,300 \mathrm{~m}^{2} ; 180,000 \mathrm{~m}^{3}\end{array}$ & $\begin{array}{l}3200 \text { m.w.e., under mountain; } \\
3 \times 10^{-4}\end{array}$ & $\begin{array}{l}50-120 \\
\mathrm{CaCO}_{3} \text { and } \mathrm{MgCO}_{3}\end{array}$ & $\begin{array}{l}3.78 \times 10^{-2} \text { (total); } \\
0.32 \times 10^{-2}(>2.5 \mathrm{MeV})\end{array}$ \\
\hline LSC & $\begin{array}{l}\text { Canfranc, Spain; } \\
\text { road tunnel }\end{array}$ & $\begin{array}{l}2 \text { halls: } 40 \times 15 \times 12 \mathrm{~m}^{3} \\
15 \times 10 \times 8 \mathrm{~m}^{3} ; \text { tot } 1000 \mathrm{~m}^{2}\end{array}$ & $\begin{array}{l}2400 \text { m.w.e., under mountain; } \\
2 \times 10^{-3}-4 \times 10^{-3}\end{array}$ & \begin{tabular}{|l|}
$50-80$ \\
limestone,
\end{tabular} & $2 \times 10^{-2}$ \\
\hline LSM & $\begin{array}{l}\text { Modane, France; } \\
\text { road tunnel }\end{array}$ & $\begin{array}{l}1 \text { hall and service areas: } \\
400 \mathrm{~m}^{2}\end{array}$ & $\begin{array}{l}4800 \text { m.w.e. under mountain; } \\
4.7 \times 10^{-5}\end{array}$ & $\begin{array}{l}15 ;(0.01 \text { filtered }) \\
\text { calcitic schists }\end{array}$ & $\begin{array}{l}5.6 \times 10^{-2} \text { (work in } \\
\text { progress) }\end{array}$ \\
\hline SLANIC & $\begin{array}{l}\text { Prahova mine, } \\
\text { Romania; vertical }\end{array}$ & $\begin{array}{l}70,000 \mathrm{~m}^{2} \text { average ht. } \\
52-57 \mathrm{~m}\end{array}$ & $208 \mathrm{~m}$, under flat surface & \begin{tabular}{|l|}
6 \\
salt
\end{tabular} & - \\
\hline SUNLAB & \begin{tabular}{|l|} 
Sieroszowice mine, \\
Poland; vertical
\end{tabular} & $85 \times 15 \times 20 \mathrm{~m}^{3}$ & $\begin{array}{l}900-950 \mathrm{~m}(2200 \mathrm{~m} . w . e .) \\
650-700 \mathrm{~m} \text { for large caverns }\end{array}$ & $\begin{array}{l}20 \\
\text { salt and copper ore }\end{array}$ & - \\
\hline SUL (Uk) & $\begin{array}{l}\text { Solotwina mine, } \\
\text { Ukraine; vertical }\end{array}$ & $\begin{array}{l}25 \times 18 \times 8 \mathrm{~m}^{3} ; 4 \text { of } 6 \times 6 \times 3 \\
\mathrm{~m}^{3} ; \text { total area } 1000 \mathrm{~m}^{2}\end{array}$ & $\begin{array}{l}1000 \text { m.w.e. under flat surface; } \\
1.7 \times 10^{-2}\end{array}$ & \begin{tabular}{|l|}
33 \\
salt
\end{tabular} & $<2.7 \times 10^{-2}$ \\
\hline \multicolumn{6}{|c|}{ Asia } \\
\hline \begin{tabular}{|l|} 
INO \\
(proposed)
\end{tabular} & $\begin{array}{l}\text { Masinagudi, India; } \\
\text { independent tunnel }\end{array}$ & $\begin{array}{l}2 \text { halls: } 26 \times 135 \times 25 \mathrm{~m}^{3} \text {; } \\
53 \times 12 \times 9 \mathrm{~m}^{3}\end{array}$ & 3500 m,w.e. & - & - \\
\hline Kamioka & \begin{tabular}{|l|}
$\begin{array}{l}\text { Japan; independent } \\
\text { horizontal }\end{array}$ \\
\end{tabular} & $\begin{array}{l}\text { Hall SK } 50 \text { m dia; } 40 \times 4 \\
\& 100 \times 4 \text { m wuth L-arm }\end{array}$ & $\begin{array}{l}2700 \text { m.w.e. } \\
3 \times 10^{-3}\end{array}$ & $\begin{array}{l}20-60 \\
\text { lead and zinc ore }\end{array}$ & $\begin{array}{l}8.25 \pm 0.58 \times 10^{-2} \text { (th) } \\
11.5 \pm 1.2 \times 10^{-2} \text { (fast) }\end{array}$ \\
\hline $\begin{array}{l}\text { Oto- } \\
\text { cosmo }\end{array}$ & $\begin{array}{l}\text { Tentsuji, Japan; } \\
\text { Indep. horizontal }\end{array}$ & $\begin{array}{l}2 \text { halls: } 50 \mathrm{~m}^{2} ; 33 \mathrm{~m}^{2} \text {; } \\
\text { total } \sim 100 \mathrm{~m}^{2}\end{array}$ & $\begin{array}{l}1400 \text { m.w.e. } \\
4 \times 10^{-3}\end{array}$ & 10 (radon reduced) & $4 \times 10^{-2}$ \\
\hline Y2L & \begin{tabular}{|l|} 
YangYang, S. \\
Korea; horizontal
\end{tabular} & $\begin{array}{l}\text { Current space: } 100 \mathrm{~m}^{2} \\
\text { Planned space: } 800 \mathrm{~m}^{2}\end{array}$ & $\begin{array}{l}\sim 2000 \text { m.w.e. } \\
2.7 \times 10^{-3}\end{array}$ & $\begin{array}{l}40-150 \\
-\end{array}$ & $8 \times 10^{-3}(1.5-6.0 \mathrm{MeV})$ \\
\hline \multicolumn{6}{|c|}{ North America } \\
\hline \begin{tabular}{|l|}
$\begin{array}{l}\text { DUSEL } \\
\text { (proposed) }\end{array}$ \\
\end{tabular} & $\begin{array}{l}\text { Homestake, } \\
\text { USA; vertical }\end{array}$ & \begin{tabular}{|l}
$7200,4500,100 \mathrm{~m}^{2}$ at \\
$1450,2200,2438 \mathrm{~m}$ dep
\end{tabular} & $\begin{array}{l}233,4100,6400,7000 \text { m.w.e. } \\
\text { under flat surface }\end{array}$ & \begin{tabular}{|l|}
$40-200($ at $1478 \mathrm{~m})$ \\
metasedimentary
\end{tabular} & - \\
\hline SNOLAB & $\begin{array}{l}\text { Creighton mine, } \\
\text { Canada; vertical }\end{array}$ & $\begin{array}{l}\text { SNO } \sim 200 \mathrm{~m}^{2} ; \text { main } 18 \times \\
15 \times 15-19.5 \mathrm{~m}^{3} ; \text { ladders } \\
6-7 \mathrm{~m} \text {; total } 46,648 \mathrm{~m}^{3}\end{array}$ & $\begin{array}{l}6001 \text { m.w.e. under flat surface } \\
3 \times 10^{-6}\end{array}$ & $\begin{array}{l}120 \text {; norite, granite } \\
\text { gabbro }\end{array}$ & $\begin{array}{l}4.7 \times 10^{-2} \text { (th) } \\
4.6 \times 10^{-2} \text { (fast) }\end{array}$ \\
\hline SUL (US) & $\begin{array}{l}\text { Soudan mine, } \\
\text { USA; vertical }\end{array}$ & $\begin{array}{l}2 \text { halls: } 72 \times 14 \times 14 \mathrm{~m} ; 82 \\
\times 16 \times 14 \mathrm{~m} ; \text { tot } 2300 \mathrm{~m}^{2}\end{array}$ & $\begin{array}{l}2000 \text { m.w.e under flat surface } \\
2 \times 10^{-3}\end{array}$ & $\begin{array}{l}300-700 \\
\text { Ely greenstone }\end{array}$ & $2 \times 10^{-2}$ (calc) \\
\hline WIPP & $\begin{array}{l}\text { Carlsbad, USA; } \\
\text { vertical }\end{array}$ & $500 \times 8 \times 6 \mathrm{~m}$ available & $\begin{array}{l}2000 \text { m.w.e. } \\
2 \times 10^{-3} \text { expected }\end{array}$ & $\begin{array}{l}<7 \\
\text { salt }\end{array}$ & $\begin{array}{l}115+/-22 \mathrm{~m}^{-2} \mathrm{~d}^{-1} \\
\text { (th+ath) }\end{array}$ \\
\hline Kimballton & $\begin{array}{l}\text { Butt Mountain, } \\
\text { USA; horizontal }\end{array}$ & $30 \times 11 \times 6 \mathrm{~m}$ & 1400 m.w.e & Paleozoic dolomite & - \\
\hline
\end{tabular}

Figure 1: Summary characteristics of the world's deep underground laboratories.

\section{Important Features of the Laboratories}

Several particular features are worth noting when comparing the laboratories (Figure 1): Firstly, the geology of the site is critical. It determines the natural radiation background - gamma from the $\mathrm{U}, \mathrm{Th}$ and $\mathrm{K}$ in the rock; neutron from rock fission and muons [7]. Extreme examples of note are sites in salt, such as WIPP, Boulby and Slanic, for which the natural rock background can be exceptionally low. In harder granite type rock, the background can be higher by 100 times or more. It is straightforward to measure these, using a Ge detector for instance, but more challenging to determine the fission and muon neutron background [8]. Interestingly, measurements confirm simulations showing that although salt provides significantly lower gamma background than for other rock, for neutrons the scattering process in salt means this background is not improved by nearly so much. Contamination by radon and its daughters is a major issue with widely different concentrations encountered in the different sites. Again salt wins here with levels typically of a few $\mathrm{Bqm}^{-3}$, compared to 100-1000 times more in some other sites (see Figure 1). The rock type and situation, 


\begin{tabular}{|c|c|c|c|c|}
\hline Site & Users (approx) & \multicolumn{2}{|l|}{ Current experiments } & Future plans \\
\hline \multicolumn{5}{|c|}{ Europe } \\
\hline BNO & $\begin{array}{l}\text { Staff } 50-60 \\
\text { Users } 30-35\end{array}$ & \multicolumn{2}{|l|}{ Neutrinos: BUST; SAGE } & Uncertain \\
\hline BUL & $\begin{array}{l}\text { Staff } 2 ; \\
\text { Users } 30\end{array}$ & \multicolumn{2}{|l|}{$\begin{array}{l}\text { Dark Matter: ZEPLIN II, ZEPLIN III, DRIFT II; Other: SKY, ongoing } \\
\text { R\&D, HPGe measurements, geophysics }\end{array}$} & $\begin{array}{l}\text { Expansion to deeper hard rock } \\
\text { underway; LAGUNA }\end{array}$ \\
\hline CUPP & $\begin{array}{l}\text { Staff } 3-6 \\
\text { Users } 10\end{array}$ & \multicolumn{2}{|l|}{ Muons: EMMA } & Expansion study; LAGUNA \\
\hline LNGS & \begin{tabular}{l|} 
Staff: $64+23$ \\
Users: 750
\end{tabular} & \multicolumn{2}{|l|}{$\begin{array}{l}\text { Dark matter: LIBRA, CRESST2, XENON10, WARP; Double Beta Decay: } \\
\text { COBRA, CUORICINO, GERDA; Solar/geo/SN/beam neutrinos: } \\
\text { BOREXINO, LVD, OPERA, ICARUS; Nuclear astrophysics: LUNA2; } \\
\text { Other: VIP, LISA, R\&D, HPGe, geology, biology, environmental studies }\end{array}$} & $\begin{array}{l}\text { MODULAr - new facility at } \\
\text { shallow depth (1200 m.w.e.) } \\
\text { proposed }\end{array}$ \\
\hline LSC & Being defined & \multicolumn{2}{|l|}{$\begin{array}{l}\text { Being defined by open call. In old lab: ANAIS, Rosebud, R\&D activity, } 4 \\
\text { HPGe detectors }\end{array}$} & LAGUNA \\
\hline LSM & $\begin{array}{l}\text { Staff } 8-9 ; \\
\text { Users } 100\end{array}$ & \multicolumn{2}{|l|}{$\begin{array}{l}\text { Dark Matter: EDELWEISS; Double beta Decay: NEMO, BiPo, TGV; } \\
\text { Other: SHIN, HPGe detectors }\end{array}$} & $\begin{array}{l}\text { ULISSE: } 2 \text { new halls: } 100 \times 24 \\
\mathrm{~m} ; 18 \times 50 \mathrm{~m} \text { (with water shield). } \\
\text { MEMPHIS, LAGUNA }\end{array}$ \\
\hline SUL (Uk) & $\begin{array}{l}\text { Staff } 14 \\
\text { Users } 11+\end{array}$ & \multicolumn{2}{|l|}{$\begin{array}{l}\text { Double Beta Decay: }{ }^{116} \mathrm{CdWO}_{4} \text { scintillators, SuperNEMO R\&D; R\&D on: } \\
\mathrm{CaWO}_{4}, \mathrm{ZnWO}_{4}, \mathrm{PbWO}_{4}, \mathrm{CaMoO}_{4} \text {, new molybdates }\end{array}$} & uncertain \\
\hline SLANIC & Variable & \multicolumn{2}{|l|}{ MicroBq laboratory and whole body counting } & $\begin{array}{l}\text { HPGe spectrometry; nuclear } \\
\text { astrophysics; LAGUNA }\end{array}$ \\
\hline SUNLAB & Being defined & \multicolumn{2}{|l|}{ Being defined } & LAGUNA \\
\hline \multicolumn{5}{|c|}{ Asia } \\
\hline \begin{tabular}{|l|l|} 
INO \\
(proposed)
\end{tabular} & \begin{tabular}{ll|} 
Staff: & $50-$ \\
100 &
\end{tabular} & $\begin{array}{l}\text { ICAL - 50 kt magnetized Fe tracking calorimeter for atmospheric } \\
\text { and very long base-line accelerator neutrinos }\end{array}$ & \multicolumn{2}{|c|}{ Plans being prepared } \\
\hline Kamioka & $\begin{array}{l}\text { Staff: } 13+2 \\
\text { Users: }>200\end{array}$ & $\begin{array}{l}\text { Neutrino astrohysics and beam: Super-Kamiokande, XMASS } \\
\text { prototype, KAMLAND; Dark Matter: NEWAGE, XMASS; Gravity: } \\
\text { CLIO; Double Beta Decay (proposed): CANDLE. }\end{array}$ & \multicolumn{2}{|c|}{$\begin{array}{l}\text { New halls: } 15 \times 21 \mathrm{~m} \text { for XMASS } 800 \\
\mathrm{~kg} ; 6 \times 11 \mathrm{~m} \text { for CANDLE; gravitational } \\
\text { antenna LCGT request; Hyper-K study }\end{array}$} \\
\hline Oto-cosmo & Users: $\sim 20$ & Double Beta Decay, Dark Matter: ELEGANTV, MOON-1, $\mathrm{CaF}_{2}$ & \multicolumn{2}{|c|}{ uncertain } \\
\hline Y2L & Users: $\sim 30$ & Dark Matter: KIMS; Double Beta Decay R\&D; HPGe & \multicolumn{2}{|c|}{ Can be expanded as desired } \\
\hline \multicolumn{5}{|c|}{ North America } \\
\hline \begin{tabular}{|l|l} 
DUSEL \\
(proposed)
\end{tabular} & \begin{tabular}{l|} 
Staff: $>80$ \\
Users: $>200$
\end{tabular} & First experiments through SUSEL inc. LUX (Dark Matter) & \multicolumn{2}{|c|}{ Expansion depends on approval } \\
\hline SNOLAB & $\begin{array}{l}\text { Staff: } \sim 30 \\
\text { Users: }>100\end{array}$ & $\begin{array}{l}\text { Neutrino astrophysics/Double Beta Decay: SNO+; Dark Matter: } \\
\text { DEAP/CLEAN, PICASSO; Letters being considered }\end{array}$ & \multicolumn{2}{|c|}{$\begin{array}{l}\text { SuperCDMS, EXO. Further site } \\
\text { expansion limited by rock removal }\end{array}$} \\
\hline SUL (US) & $\begin{array}{l}\text { Staff: } 9 \\
\text { Users: }>200\end{array}$ & Neutrino beam: MINOS; Dark Matter: CDMS II; low background & \multicolumn{2}{|c|}{ uncertain } \\
\hline WIPP & $\begin{array}{l}\text { Staff: as } \\
\text { needed }\end{array}$ & Double Beta Decay R\&D: EXO, MEGA/SEGA, MAJORANA & \multicolumn{2}{|c|}{ Expansion to fill designated area } \\
\hline Kimballton & $\begin{array}{l}\text { Staff: as } \\
\text { needed }\end{array}$ & Neutrino astrophysics: LENS, R\&D & \multicolumn{2}{|c|}{ Expansion to fill designated area } \\
\hline
\end{tabular}

Figure 2: Deep underground experiments and plans.

including seismic activity, faulting, water ingress and other geology, also determines the form of cavern that can be constructed, notably the height. Salt, for instance, undergoes plastic flow which restricts the excavations at depth. However, at shallower depths, such as Slanic, this restriction relaxes. Here extraordinary caverns of 40-50m in height have been in use for over 100 years (see Figure 3 ). To create larger caverns at depth, harder rock, such as at Gran Sasso is essential.

\section{Geographic Issues}

A second issue is the division between tunnel-based and mine-based sites. The advantages held by the former are often cited, for instance the benefits of horizontal access. However, while horizontal access may be an advantage during experiment construction, for the user vertical, walkin, lift access, can be more convenient. Meanwhile, mine companies, such as INCO at SNOLAB or CPL at Boulby, are anyway well used to transporting large items down shafts and fabricating underground. One concern is safety. This is key to both but particularly for tunnels because of the presence of the general public, in contrast with a mine where access for everyone is strictly 


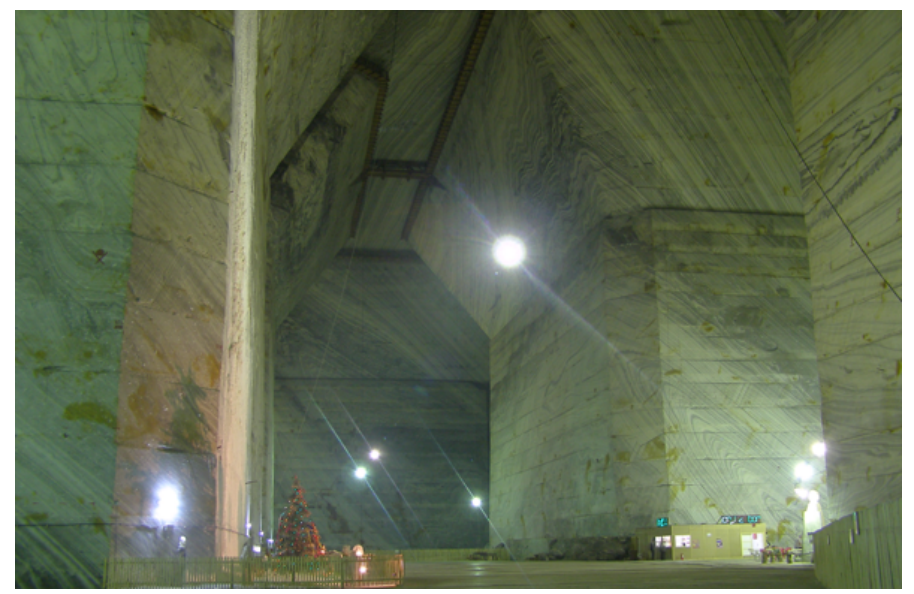

Figure 3: The Slanic site in Romania - a relatively shallow site but with exceptionally large caverns excavated in salt (thanks to Romulus Margineanu).

controlled. This control may make mine sites more suitable for future experiments requiring unusual or potentially dangerous materials. There is also ready prospect for new excavation to allow interdisciplinary science through access to fresh, uncontaminated rock.

The geographic location is a further point to note. All current deep laboratories are located in relatively remote, rural areas with limited transport and accommodation options. These are challenges for the laboratory directors but arguably worse are the environmental challenges, particularly in Europe where all four deep sites are in national parks. This has, for instance, restricted surface laboratory development at Boulby, and at Gran Sasso has halted expansion plans in part due to the environmental impact on the local water table. More importantly, site location is vital to certain science activity, notably neutrino physics. Here, if the best neutrino oscillation physics is to be extracted then the distance to a potential next generation neutrino beam or factory needs to be optimised, depending on the beam energy. Long baselines favor better separation of matter effects from CP violation and provide a richer neutrino physics, including determining the MNSP matrix elements [9]. Thus, for instance, the proximity of Frejus to CERN (130 km) may disfavour this site in certain scenarios. The relative remoteness of a site like Phyasalmi, away from commercial nuclear energy reactors is also a consideration. The anti-neutrino background from these is, for instance, a limiting factor for new experiments seeking to observe the background neutrino flux from past supernova or geo-neutrinos [10] and [11].

\section{Science and Expansion}

Figure 2 lists most of the current activity underground. The recent success of Borexino at Gran Sasso is a particular milestone, not just for successfully observing ${ }^{7} \mathrm{Be}$ solar neutrinos in real time but because this experiment has demonstrated the feasibility of achieving backgrounds in a large (87.9 ton, fiducial) active medium, liquid scintillator in this case, at the exceptional level of $7 \times 10^{-18} \mathrm{~g} / \mathrm{g}{ }^{323} \mathrm{Th}$. Such progress points the way to building much larger detectors at depth, notably a 100-1000 Kton experiment to push proton decay sensitivity by one to two orders. Such a detector could also measure the relic neutrino flux from past supernovae and, with a suitable beam, unravel lepton CP violation. The LAGUNA collaboration, now part-funded by the European Commission, will study three potential technologies in this area, water cherenkov, liquid argon and 
liquid scintillator, and investigate options for a new underground laboratory at Boulby (UK), Canfranc (Spain), Frejus (France), in Italy, Phyasalmi (Finland), Slanic (Romania) or Sunlab (Poland). In Japan, similar plans are well advanced with detailed rock studies in the region of Kamioka mine already completed [12] and [13].

The development of LAGUNA is evidence of the vibrancy in underground science in general, with new sites emerging, such as the Indian Neutrino Observatory (INO), and many expansions underway (see Figure 2). In particular, the fields of dark matter and neutrino physics are maturing and will need a new generation of larger, multi-tonne, experiments. The Canfranc halls have recently been built with this in mind and at Frejus, ULISSE is well advanced to establish two new halls totalling $>3000 \mathrm{~m}^{2}$, including an integrated water shield. Meanwhile, at Boulby, there are prospects new areas and at Phyasalmi, now the deepest mine in Europe at $1400 \mathrm{~m}$, engineers are proposing a new facility separated from the main mining activity. Worldwide, the best know expansion activities are at SNOLAB and DUSEL. The former includes the new Cryopit Laboratory that will be the world's first underground site dedicated specifically to liquid noble gas experiments.

Acknowldgements: the author would like to thank ILIAS (contract no. RII3-CT-2004-506222) and CPL (Boulby) for support.

\section{References}

[1] www.lbl.gov/nsd/homestake/

[2] L. Kaufmann ate al., Nucl. Phys. B - Proc. Supp. 173, (2007), 141

[3] A. Bettini, Proc. TAUP2007 - www.iop.org/EJ/volume/1742-6596/120/8

[4] M. Laubenstein

[5] J. Aysto et al., JCAP 0711 (2007) 011

[6] www-ilias.cea.fr

[7] E. Tziaferi et al., Astroparticle Physics 27(2007) 326

[8] www-lsm.in2p3.fr/

[9] V. Barger et al, arxiv.org/abs/0705.4396

[10] A. Kathrin et al., Astroparticle Physics 27(2007) 21

[11] C. Arpesella et al., Phys. Lett. B 658 (2008) 101

[12] N. Wakabayashi, proc. NNN07 - www-rccn.icrr.u-tokyo.ac.jp/NNN07

[13] A. Rubbia et al., arXiv:0804.2111 